УДК 94(437.6+477) «1941»:[358.1+623.4]

ХАРУК А. I.

https://orcid.org/0000-0003-3459-1657

ЄФИМЕНКО Г. А.

https://orcid.org/0000-0003-1106-4010

https://doi.org/10.33577/2313-5603.33.2020.111-121

\title{
СЛОВАЦЬКА АРТИЛЕРІЯ У БОЙОВИХ ДІЯХ ПОЧАТКОВОГО ЕТАПУ НІМЕЦЬКО-РАДЯНСЬКОЇ ВІЙНИ (КІНЕЦЬ ЧЕРВНЯ - СЕРЕДИНА СЕРПНЯ 1941 РОКУ)
}

У статті розглянуті питання участі артилерії Словаччини в бойових діях перших тижнів німецько-радянської війни, досліджена ії організація та матеріальна частина. Основна увага звернута на артилерійські підрозділи Рухомої групи, згодом реорганізованої в Рухому бригаду. Також розглянуто організацію і бойовий шлях артилерії Армійської групи. Визначено, що артилерія армії Словаччини використовувала колишні чехословацькі взірці, здебільшого морально застарілі. Однак для фронтового авангарду - Рухомої бригади - були виділені найбільш сучасні артилерійські системи. Іншою характерною рисою словацької артилерії було домінування у їі парку гаубиць. Відзначено, що саме артилерія відіграла значну роль у найбільшому бойовому зіткненні словацьких частин у досліджуваний період бою під Липовцем 22-23 липня 1941 р.

Ключові слова: артилерія, Друга світова війна, німецько-радянська війна, Словаччина, Україна.

Постановка проблеми та ї̈ актуальність. На початковому етапі війни проти СРСР в бойових діях на території України крім німецьких військ брали участь й армії союзників, зокрема Словаччини. Ця країна виставила відносно невеликий контингент, у якому були представлені усі основні роди зброї. Помітну роль у бойових діях відігравали артилерійські частини. Дослідження їхньої організації, озброєння та бойового шляху сприятиме більш повному відтворенню історії подій німецько-радянської війни, що відбувались на теренах України.

Аналіз попередніх досліджень і публікаиій. Мусимо констатувати, що в українській історіографії досі практично відсутні дослідження, присвячені питанням участі словацьких артилерійських частин у бойових діях на території України. Серед словацьких публікацій повнотою охоплення матеріалу відзначаються праці П. Мічаніка.

Харук Андрій Іванович, доктор історичних наук, професор, завідувач кафедри гуманітарних дисциплін Національної академії сухопутних військ імені гетьмана Петра Сагайдачного, м. Львів.

Єфименко Ганна Адамівна, молодший науковий співробітник науковоорганізаційного відділу Центру воєнно-стратегічних досліджень Національного університету оборони України імені Івана Черняховського, м. Київ.

(C) Харук А.І., Сфименко Г.А., 2020. 
У них, зокрема, досліджено бойовий шлях Рухомої групи в перші дні війни (Mičianik, 2004), детально розглянуто підготовку, хід і підсумки найбільшого бойового зіткнення Рухомої бригади - бою під Липовцем 22-23 липня 1941 р. (Mičianik, 2005), а також подано загальну характеристику участі Словаччини у війні проти CРСР у 1941 р. (Mičianik, 2007). Бою під Липовцем присвячена i стаття Т. Клуберта (Klubert, 2003), однак за інформаційним наповненням і рівнем опрацювання матеріалу вона прогає згаданій вище роботі П. Мічаніка. Дослідження С. Клімента та Б. Накладала зосереджене головно на організації та озброєнні словацької армії, а ось ідеологічних та пропагандистських аспектів вони майже не торкаються (Kliment, Nakládal, 2003). Для аналізу матеріальної частини словацької артилерії надзвичайно корисною є робота В. Карліцкого (Karlický, 1975). Хоч вона і є далеко не новою, більш повного дослідження матеріальної частини чехословацької (і словацької) артилерії досі не вийшло. Доповнити окремі аспекти нашої розвідки дозволили дані, вміщені в статтях I. Баки (Baka, 2008), Й. Пеціни (Pecina, 2005), 3. Мурарікової (Muráriková, 2013).

Мета та завдання дослідження. У нашій розвідці ми маємо за мету проаналізувати організаційну структуру та озброєння артилерійських частин словацького військового контингенту, який діяв на території України, а також дослідити їхню участь у боях. Хронологічні межі дослідження охоплюють період 3 кінця червня 1941 р. (вступу Словаччини у війну проти СРСР) до середини серпня 1941 р. (завершення процесу скорочення та реорганізації словацького військового контингенту).

Виклад основного матеріалу дослідження. Формування збройних сил Словаччини почалось після проголошення 14 березня 1939 р. незалежності країни. Нова держава стала сателітом Німеччини, що було формально закріплено в укладеному 23 березня того ж року «Договорі захисту». Цей документ підпорядкував словацьку зовнішню, військову та економічну політику інтересам Третього рейху.

Формування словацьких збройних сил відбувалось на базі кадрів, озброєння і техніки частин і з'єднань армії колишньої Чехословаччини, дислокованих на території Словаччини (три штаби корпусів, шість піхотних і одна рухома дивізії). Процес цей значно ускладнювався кадровим «голодом». Станом на 1935 р. у чехословацькій армії служили 52\% чехів, 22\% німців і лише 14\% словаків. У 1937 р. словаки становили тільки 3,9\% офіцерського корпусу армії Чехословаччини, а серед генералів лише 
один був словаком за національністю (Kliment \& Nakládal, 2003: 20). Після проголошення незалежності Словаччини усі чехи були звільнені зі словацької армії i, як наслідок, - корпусами й дивізіями спочатку командували майори і капітани (Kliment \& Nakládal, 2003: 23). Значно кращою була ситуація з озброєнням словацька армія «успадкувала» все майно чехословацьких частин і з'єднань, дислокованих у Словаччині. Станом на серпень 1939 р. словацька армія мала 526 гармат і гаубиць, у тому числі 99 гірських 75-мм гармат vz. 15, 13 76,5-мм (офіційно - 8-см) польових гармат vz. 30, 263 100-мм гаубиці (195 vz. 14/19, 38 vz. 16/19 i 30 vz. 30), 36 105-мм гармат vz. 35, а також 115 150-мм гаубиць vz. 25 (Kliment \& Nakládal, 2003: 44). Усі вони були виготовлені фірмою «Шкода». Тактико-технічні характеристики артилерійських систем словацької армії наведені в таблиці 1, складеній за довідником В. Карліцкого (Karlický, 1975).

Таблиия 1

\section{Тактико-технічні характеристики артилерійських систем армії Словаччини}

\begin{tabular}{|c|c|c|c|c|c|c|c|}
\hline Тип артсистеми & 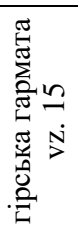 & 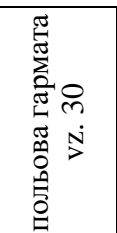 & 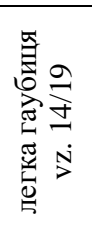 & 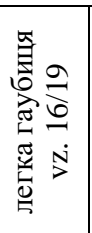 & 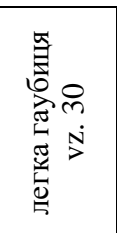 & 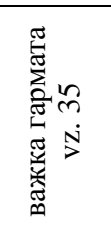 & 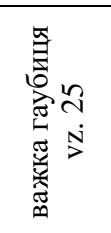 \\
\hline Калібр, мм & 75 & 76,5 & 100 & 100 & 100 & 105 & 150 \\
\hline Довжина ствола, мм & 1155 & 2941 & 2400 & 2400 & 2500 & 4400 & 2700 \\
\hline $\begin{array}{l}\text { Довжина нарізної } \\
\text { частини ствола, мм }\end{array}$ & 795 & 2392 & 1888 & 1888 & 1939 & 3258 & \\
\hline $\begin{array}{l}\text { Кут вертикального } \\
\text { наведення, град. }\end{array}$ & $\begin{array}{r}-9 \\
+50 \\
\end{array}$ & $-8,+80$ & $\begin{array}{l}-7 \\
+48 \\
\end{array}$ & $\begin{array}{l}-7,5 \\
+70 \\
\end{array}$ & $-8,+80$ & $-6,+42$ & $-5,+70$ \\
\hline $\begin{array}{l}\text { Кут горизонтально- } \\
\text { го наведення, град. }\end{array}$ & 7 & 8 & 6 & 6 & 8 & 50 & 14 \\
\hline $\begin{array}{l}\text { Швидкострільність, } \\
\text { постр./хв }\end{array}$ & $6-8$ & $10-12$ & $6-8$ & $6-8$ & $6-8$ & 8 & 3 \\
\hline $\begin{array}{l}\text { Маса у бойовому } \\
\text { положенні, кг }\end{array}$ & 615 & 1816 & 1505 & 1350 & 1798 & 4200 & 3740 \\
\hline Маса снаряда, кг & 6,3 & 8 & $10-13,6$ & $10-13,6$ & 16 & 18 & 42 \\
\hline $\begin{array}{l}\text { Максимальна по- } \\
\text { чаткова швидкість } \\
\text { снаряда, м/с }\end{array}$ & 349 & 600 & 407 & 407 & 430 & 730 & 450 \\
\hline $\begin{array}{l}\text { Максимальна даль- } \\
\text { ність стрільби, м }\end{array}$ & 8250 & 13500 & 9970 & 9800 & 10600 & 18000 & 11800 \\
\hline $\begin{array}{l}\text { Чисельність } \\
\text { обслуги, чол. }\end{array}$ & 6 & 6 & 6 & 6 & 6 & 9 & 8 \\
\hline
\end{tabular}


Переважна більшість артилерійських систем, за влучним висловом Й. Пеціни, належали до «старонових», тобто фізично мало зношених, але морально застарілих (Ресіпа, 2005: 56). Сучасними були лише гармати vz. 30 i vz. 35 та гаубиці vz. 30 - всього 87 одиниць, тобто 16,5\%. Тільки ці два типи артсистем (та ще гармати vz. 30 - але через мізерну кількість їх вилучили з військ i відправили на склади) могли буксируватись механічною тягою решта мали непідресорений колісний хід, придатний лише для кінної тяги. Лафет сучасної конструкції лафета з розсувними станинами, який забезпечував великий кут горизонтального наведення, мала тільки гармата vz. 35. Усі інші артсистеми мали однобрусні лафети з обмеженим кутом горизонтального наведення. На території Словаччини, у місті Дубниця-над-Вагом, розташовувався один із заводів концерну «Шкода». У 1941 р. він почав випуск стандартних німецьких польових гаубиць - 105-мм leFH 18 i 150-мм sFH 18 (Muráriková, 2013: 14). Однак це підприємство знаходилось під німецьким контролем і постачало свою продукцію для вермахту. Спроби ж Словаччини отримати сучасні німецькі артсистеми - 105-мм гаубиці leFH 18 і гармати К 18 такого ж калібру - у 1941 р. успіхом не увінчались (Baka, 2008: 58).

Наявна кількість артилерійських систем була надмірною 3 огляду на невелику чисельність армії Словаччини - дві піхотні дивізії та низка окремих частин. Після реорганізації армії, завершеної 1 жовтня 1940 р., до складу піхотних дивізій входили 1-й і 2-й артилерійські полки, озброєні 100-мм гаубицями на кінній тязі (у кожному полку - 42 гаубиці vz. 14/19 і 13 vz. 16/19). Окремий 11-й (моторизований) артполк мав 27 100-мм гаубиць vz. 30 і таку ж кількість 105-мм гармат vz. 35. Як тягачі використовувались тривісні армійські автомобілі - «Прага» RV для 100-мм гаубиць і «Шкода» 6ST6 для 105-мм гармат. Нарешті, 12-й (важкий) артполк мав 49 150-мм гаубиць vZ. 25 на кінній тязі (Mičianik, 2007: 21). 75-мм гірські гармати vz. 15 використовувались як піхотна артилерія - ними озброїли батареї гірських гармат у складі піхотних полків. Таким чином, напередодні початку німецько-радянської війни дивізійна артилерія армії Словаччини складалась виключно з гаубиць - це відповідало тенденціям розвитку артилерії цієї ланки напередодні Другої світової війни (Харук, 2017: 368). Домінування кінної тяги в артилерії аж ніяк не свідчить про відсталість словацької армії - скажімо, у 
піхотних дивізіях вермахту уся артилерія теж була на кінній тязі (Ткачук \& Харук \& Красюк, 2016: 12).

22 червня 1941 р. (у день нападу Німеччини на СРСР) розпочалась прихована мобілізація (Katreba, 2000: 88). В той же день ЗС Словаччини були приведені у повну бойову готовність, а міністр національної оборони генерал I рангу Фердінанд Чатлош наказав сформувати Рухому групу (дослівно - Rýchla skupina, тобто «Швидка група»), яка мала взяти участь у війні проти СРСР в підпорядкуванні німецької 17-ї армії групи армій «Південь» (Mičianik, 2004: 49). До складу останньої увійшли моторизований піхотний і танковий батальйони, розвідувальний дивізіон, підрозділи забезпечення, а також 1-й дивізіон 11-го артполку (у словацькій армії було прийняте написання номера частини типу I/11; цього будемо дотримуватись й ми). Останній складався 3 трьох вогневих батарей і взводу зв'язку. Чисельність особового складу дивізіону становила 250 осіб (у т.ч. 5 офіцерів). На озброєнні знаходились 9 гаубиць vz. 30, а транспортні засоби були представлені 34 вантажними і 7 легковими автомобілями, 3 мотоциклами і 6 велосипедами. Крім того піхотний батальйон Рухомої групи мав 4 гірські гармати vz. 15 (Kliment \& Nakládal, 2003: 84).

Після полудня 24 червня 1941 р. підрозділи Рухомої групи перетнули лінію словацько-радянського кордону і вступили на територію Дрогобицької області УРСР (з березня 1945 р. ці землі належать Польщі). Група була оперативно підпорядкована німецькій 454-й охоронній дивізії. Словаки отримали наказ просуватись до Кросьценко, звідки відправити розвідку до Хирова. Після полудня 25 червня розвідувальний підрозділ і танковий батальйон Рухомої групи форсували р. Сян в районі Темешова (15 км на північ від м. Сянок). Однак автомобілі піхотного батальйону і I/11 артдивізіону не могли подолати річку убрід, і ці підрозділи лишились на західному березі Сяну. I/11 артдивізіон був оперативно підпорядкований 221-му артполку 454-ї дивізії і виконував вогневі завдання з підтримки підрозділів цієї дивізії (Mičianik, 2007: 68-69). Коли 27 червня Рухома група отримала завдання очистити територію в районі м. Сянок, де ще оборонялись гарнізони кількох ДОТів Перемишльського укріпленого району, виконувати це завдання довелось без підтримки артдивізіону. Чотири 75-мм гірські гармати, придані піхотному батальйонові, були безсилі проти бетонованих укріплень. Тому 
єдиним способом зламати опір гарнізонів ДОТів стала облога. 29 червня Рухома група зосередилась в с. Садковичі, де до неї приєднався I/11 артдивізіон. 1 липня група перемістилась до Самбора (Mičianik, 2004: 59-62).

Упродовж 5-7 липня 1941 р. Рухома група була посилена низкою підрозділів і розгорнута у Рухому бригаду. Зокрема, вона отримала ще одну батарею 11-го артполку - 8/11, яка була озброєна чотирма 105-мм далекобійними гарматами vz. 35. Ця батарея увійшла в підпорядкування I/11 дивізіону. Крім того, очевидно, три наявні гаубичні батареї отримали по четвертій гаубиці - бо станом на 8 липня Рухома бригада мала 12 гаубиць vz. 30 i 4 гармати vz. 35, а також 4 гармати vz. 15 в батареї гірських гармат. 11 липня бригада передислокувалась до містечка Козлів (східніше Тернополя), а наступного дня отримала радикальне посилення - 11-й артполк у повному складі. Його I/11 i II/11 дивізіони мали по 12 гаубиць vz. 30, а III/11 дивізіон 12 гармат vz. 35. Чисельність особового складу артполку становила 1559 осіб, а командував ним майор Ян Калло (Kliment \& Nakládal, 2003: 87). Завдяки цьому посиленню Рухома бригада отримала артилерійську складову рівня дивізії. При цьому в іiі складі лишались лише один танковий батальйон та посилений мотопіхотний батальйон, а також моторизований розвідувальний дивізіон і підрозділи забезпечення.

16 липня Рухома бригада прибула до Городка (Тернопільска обл.), де отримала кілька днів перепочинку, необхідного для ремонту автомобілів і танків. Увечері 19 липня словацьке з'єднання передали у підпорядкування німецького 49-го гірського корпусу (1-ша і 4-та гірські, 257-ма піхотна дивізіі). Рухома бригада суттєво посилила німецький корпус, який досі не мав у своєму складі жодного моторизованого з'єднання (Klubert, 2003: 16).

21 липня 1941 р. Рухома бригада отримала наказ командира 49-го гірського корпусу висунутись в район Липовець-Іллінці (40-50 км на схід від Вінниці), щоб перекрити частинам Червоної Армії шляхи відступу на південь і південний схід. Переночувавши в с. Щаслива (за 7 км від Липовця), о 4:30 22 липня словацькі передові дозори рушили до Липовця, де зайняла оборону радянська 44-та гірська стрілецька дивізія (ГСД). Радянські передові позиції знаходились за 3 км від Липовця. Станом на 6 ранку бій під Липовцем вів розвідувальний дивізіон Рухомої 
бригади, посилений двома взводами танків, ротою піхоти і I/11 дивізіоном 100-мм гаубиць. О 10 годині зайняв вогневі позиції і відкрив вогонь також II/11 дивізіон. Невдовзі опір бойової охорони 44-ї ГСД вдалось зламати (Mičianik, 2007: 103-106). Словаки зайняли вихідні позиції для загальної атаки на Липовець. О 12.30 11-й артполк у повному складі почав артилерійську підготовку. У відповідь радянська артилерія розпочала обстріл словацьких батарей. Одна 3 гармат III/11 дивізіону близьким вибухом була перекинута. Саме цей дивізіон зазнавав найсильнішого обстрілу, внаслідок чого йому довелось кілька разів змінювати вогневі позиції (Mičianik, 2005: 223). Спроба контратаки силами 319-го гірського стрілецького полку була відбита при підтримці танків і артилерії, і близько 15 години словацькі підрозділи вийшли на північну і західну околиці Липовця. Артилерійські батареї зайняли позиції на висотах на захід від містечка, однак ввечері їх відвели за с. Щаслива через постійні контратаки противника - ворожі піхотинці наблизились до позицій на відстань 500 м, і навіть важкі 105-мм гармати змушені були вести вогонь прямою наводкою. Одну пошкоджену гаубицю довелось залишити, знявши замок, але за деякий час під прикриттям концентрованого артилерійського вогню словаки зуміли іiі евакуювати. Активно діяла в бою 22 липня і батарея гірських гармат - iіi розрахунки переміщували гармати vz. 15 слідом за наступаючою піхотою і забезпечували безпосередню підтримку (Mičianik, 2005: 229-232). Вибити частини 44-ї ГСД з Липовця словакам вдалось тільки наступного дня завдяки підтримці німецьких частин. За два дні боїв Рухома бригада зазнала суттєвих втрат - 75 загиблих, 167 поранених, 19 полонених (Kliment \& Nakládal, 2003: 92). Причинами втрат, які сягали 5\% особового складу бригади, були визнані погана розвідка (словацькі підрозділи фактично вели бій наосліп, не знаючи сил противника) і нестача піхоти, спроможної ефективно підтримати танки у вуличних боях. Артилерія ж показала себе 3 найкращого боку. Втрати ії теж були мінімальними - тільки троє поранених в батареї гірських гармат (Klubert, 2003: 34-35).

Після бою під Липовцем основні сили Рухомої бригади передали свою ділянку фронту підрозділам німецької 295-ї піхотної дивізії і були відведені в тил задля розгортання з бригади в дивізію. Однак це не стосувалось 11-го артполку і моторизованого розвідувального дивізіону - їх залишили на фронті і тимчасово 
підпорядкували 295-й дивізії. 26 липня, під час бою за с. Кальник, одна з батарей 11-го артполку зазнала нальоту радянських винищувачів, однак втрат не було. 30 липня, під час маршу до Умані, поблизу с. Гранів (на північний схід від Гайсина) один $з$ дивізіонів артполку був атакований радянською стрілецькою ротою. Словацькі джерела вказують, що атаки зазнав дивізіон III/1, але він був озброєний 105-мм гарматами vz. 35, тим часом серед втрат фігурують лише гаубиці vz. 30. Внаслідок бою словаки втратили 8 чоловік загиблими і 8 пораненими, 7 гаубиць і 2 автомобілі «Прага» RV. Після цього бою 11-й артполк вивели 3 фронту (Mičianik, 2005: 240-241).

Поряд з Рухомою групою Словаччина виставила для участі у війні проти СРСР значно чисельніший другий ешелон - Армійську групу у складі 1-ї та 2-ї піхотних дивізій і частин підтримки та забезпечення. Артилерійська складова була представлена артполками дивізій (1-м та 2-м) зі 100-мм гаубицями на кінній тязі. Зокрема, перший $з$ них мав 32 гаубиці vz. 14/19 (до штатного складу бракувало однієї батареї), а другий - 24 vz. 14/19 і 12 vz. 16/19; крім того, кожен з трьох піхотних полків в цих дивізіях мав батарею $з$ чотирьох 75-мм гармат vz. 15. До складу Армійської групи входили і два окремі артполки: 11-й (без II/11 дивізіону, виділеного до Рухомої групи; 15 гаубиць vz. 30 і 12 гармат vz. 35) і 12-й (36 150-мм гаубиць vz. 25) (Mičianik, 2007: 138). 1 липня частини Армійської групи перейшли лінію словацькорадянського кордону. Її частини брали участь у придушенні опору останніх ДОТів «лінії Молотова», однак жодна інформація про дії артилерії в цих боях відсутня. 6 липня Армійська група була зосереджена в районі Добромиль-Хирів-Старий Самбір. В цей час іiі моторизовані підрозділи (у тому числі 11-й артполк) передали до складу Рухомої бригади. 10 липня 1-ша ПД знаходилась в районі Рудки-Львів, 2-га ПД - в околицях Дрогобича. 11 липня Армійська група була підпорядкована командуванню Тилового району групи армій «Південь» і отримала завдання замінити німецьку 444-ту охоронну дивізію в районі СамбірМиколаїв-Стрий задля дотримання тут порядку і ліквідації розпорошених груп червоноармійців. Ці завдання словаки виконували до 13 липня, але виключно силами піхоти - артилерія для 
цього була непотрібна . 30 липня поблизу с. Любінь Великий (під Львовом) словаки провели перевірку протитанкових можливостей своїх артсистем. Мішенями служили покинуті на полі бою танки - легкий БТ-7 і середній Т-34. Крім протитанкових і танкових гармат у випробуванні взяли участь 75-мм гармата vz. 15 i 100-мм гаубиця vz. 14/19. Виявилось, що осколково-фугасні снаряди обох артсистем спроможні розірвати гусениці танків, а близький вибух 100-мм снаряда може вивести зі строю танк БТ-7. Однак в бою перевірити ці можливості вказаних артсистем не довелось. 39 до 16 серпня 1941 р. більшість частин Армійської групи були виведені до Словаччини. На території СРСР залишились два з'єднання - Рухома і Охоронна дивізії (Kliment \& Nakládal, 2003: 93).

Висновки. Виходячи з проведеного нами аналізу можна стверджувати, що напередодні вступу у війну проти СРСР Словаччина мала достатньо чисельний, хоч i не надто сучасний, артилерійський парк. Однак використання його в перші тижні бойових дій було дуже обмеженим. Фактично, активні бойові дії вели тільки артилерійські підрозділи Рухомої групи, реорганізованої в Рухому бригаду - спочатку один дивізіон (9 гармат), а згодом артилерійський полк (36 гармат). Для цього словацьке командування виділило найбільш сучасні артилерійські системи на механічній тязі - 100-мм гаубиці vz. 30 і 105-мм гармати vz. 35. Крім того, як піхотні гармати використовувалась невелика кількість 75-мм гірських гармат vz. 15. Артилерія Рухомої бригади продемонструвала високу ефективність у ході найбільшого в досліджуваний період бойового зіткнення за участю словацьких військ - бою за Липовець 22-23 липня 1941 р. Саме успішні дії артилерії, зрештою, стали одним $з$ вирішальних чинників перемоги словаків.

Друга складова словацького контингенту, виділеного для участі у війні проти СРСР, - Армійська група - мала значно сильнішу артилерійську складову. До неї спочатку входили чотири артилерійські полки - два у складі дивізій і два окремих. Однак жодних бойових завдань за своїм прямим призначенням вони не виконували. Пояснюється це тим, що Армійська група несла службу в тиловому районі і виконувала функції з підтримання порядку на окупованій території. 


\section{Використані посилання}

Ткачук П., Харук А., Красюк О. (2016) Польова артилерія Другої світової війни: Історичний нарис. Львів: НАСВ, 194 с.

Харук А. (2017) Питання гаубизації дивізійної артилерії напередодні Другої світової війни. Перспективи розвитку озброєння та військової техніки сухопутних військ: Збірник тез доповідей Міжнародної науково-технічної конференції (Львів, 11-12 травня 2017 р.), с. 368.

Baka I. (2008) Účast' Slovenskej republiky v prvej fáze vojny proti ZSRR z pohl'adu nemeckých vojenských orgánov. Vojenská história, №3, P. 47-65.

Karlický V. (1975) Československé dělostrělecké zbrané. Praha: Naše vojsko, 380 p.

Katreba Z. (2000) «Skrytá» mobilizácia na Slovensku v roku 1941. Vojenská história, № 3-4, P. 87-100.

Kliment C., Nakládal B. (2003) Slovenská armáda 1939-1945. Praha: Naše vojsko, 364 p.

Klubert T. (2003) Boj pri Lipovci. Vojenská história, №1, p. 15-35.

Mičianik P. (2004) Slovenská Rýchla skupina v začiatočnej fáze operácie Barbarossa. Vojenská história, № 4, P. 47-65.

Mičianik P. (2005) Slovenská Rýchla brigáda a bitka pri Lipovci. Historické rozhl'ady, № 2, P. 199-248.

Mičianik P. (2007) Slovenská armada v t’ažení proti Sovietskemu zväzu (19411944). I. V operacii Barbarossa. Bratislava: Dali-BB, 296 p.

Muráriková Z. (2013) Śkodove závody v Dubnici nad Váhom v rokoch 1938 1945. Vojenská história, № 4, P. 6-30.

Pecina J. (2005) Pol'né delostrelectvo Rýchlej divizie 1941 - 1942 (Od Kyjeva po rieku Mius). Vojenská história, № 1, P. 56-73.

\section{References}

Baka I. (2008) Participation of the Slovak Republic in the first phase of the war against ZSSR from the perspective of German military authorities. Vojenská história, № 3, P. 47-65 (slovak).

Karlický V. (1975) Czechoslovak artillery weapons. Praha: Naše vojsko, 380 p. (czech).

Katreba Z. (2000) «Hidden» mobilization in Slovakia in 1941. Vojenská história, № 3-4, P. 87-100 (slovak).

Kharuk A. (2017) The question of howitzing divisional artillery on the eve of World War II. Prospects for the development of the armament and military equipment of the ground forces: Proceedings of the International Scientific and Technical Conference (Lviv, May 11-12, 2017), P. 368 (ukr).

Kliment C., Nakládal B. (2003) Slovak Army 1939-1945. Praha: Naše vojsko, 364 p. (czech).

Klubert T. (2003) Fight at Lipovec. Vojenská história, №1, p. 15-35 (slovak).

Mičianik P. (2004) Slovak Rapid Group in the initial phase of Operation Barbarossa. Vojenská história, № 4, P. 47-65 (slovak).

Mičianik P. (2005) Slovak Rapid Brigade and Battle of Lipovec. Historické rozhl'ady, № 2, P. 199-248 (slovak). 
Mičianik P. (2007) Slovak Army in campaign against Soviet Union (1941 - 1944). Vol. I. In Operation Barbarossa. Bratislava: Dali-BB, 296 p. (slovak).

Muráriková Z. (2013) Śkoda's factories in Dubnici nad Váhom in 1938 - 1945. Vojenská história, № 4, P. 6-30 (slovak).

Pecina J. (2005) Field Artillery of the Rapid Division 1941 - 1942 (From Kiev to the Mius River). Vojenská história, № 1, P. 56-73 (slovak).

Tkachuk P., Kharuk A., Krasiuk O. (2016) World War II Field Artillery: An Historical Sketch. Lviv: NASW, 194 p. (ukr).

\section{Kharuk A., Yefymenko H.}

\section{SLOVAK ARTILLERY IN THE FIGHTING OF THE INITIAL PHASE OF THE GERMAN-SOVIET WAR (LATE JUNE - MID-AUGUST 1941)}

At the initial stage of the war against the USSR, in addition to German troops, Allied armies, including Slovakia, participated in the fighting on the territory of Ukraine. This country exhibited a relatively small contingent, representing all major arms. A significant role in the fighting played artillery units.

On the eve of the war against the USSR, Slovakia had a large, though not too modern, artillery park (the share of modern artillery systems was $16.5 \%$ ). However, its use in the first weeks of combat was very limited. In fact, only the artillery units of the Mobile Group reorganized into the Mobile Brigade were active in combat, initially one division (9 guns) and later an artillery regiment (36 guns). For this purpose the Slovak command has allocated the most modern artillery systems on mechanical traction $-100 \mathrm{~mm}$ howitzer vz. 30 and $105 \mathrm{~mm}$ guns vz. 35 . In addition, infantry guns used a small number of $75 \mathrm{~mm}$ mountain guns vz. 15. The Mobile Brigade artillery demonstrated high efficiency during the largest fighting in the studied period with the participation of Slovak troops - the battle of Lipovec on July 22-23, 1941.

The second component of the Slovak contingent allocated to participate in the war against the USSR, the Army Group, had a significantly stronger artillery component. It initially consisted of four artillery regiments - two in divisions and two separate. However, they did not carry out any combat tasks by their intended purpose. This is compounded by the fact that the Army Group served in the rear area and performed order maintenance activities in the occupied territory.

All the artillery pieces used by the Slovak army were manufactured by Skoda. Among them were dominated by $100 \mathrm{~mm}$ howitzers of three different models vz. $14 / 19$, vz. $16 / 19$ and vz. 30 . The most modern model of artillery was the $105 \mathrm{~mm}$ heavy cannon vz. 35 . Mountain $75 \mathrm{~mm}$ guns vz. 15 were used to directly support infantry.

Keywords: artillery, World War II, German-Soviet war, Slovakia, Ukraine. 